\title{
The Problem of Natural Inequality: A New Problem of Evil
}

Moti Mizrahi

St. John's University

Forthcoming in Philosophia: Philosophical Quarterly of Israel

\begin{abstract}
In this paper, I argue that there is a kind of evil, namely, the unequal distribution of natural endowments, or natural inequality, which presents theists with a new evidential (not logical or incompatibility) problem of evil. The problem of natural inequality is a new evidential problem of evil not only because, to the best of my knowledge, it has not yet been discussed in the literature, but also because available theodicies, such the free will defense and the soulmaking defense, are not adequate responses in the face of this particular evil, or so I argue.
\end{abstract}

Keywords: free will defense; moral evil; natural evil; natural lottery; problem of evil; soulmaking defense

\section{The problem of evil}

According to traditional Western theism, God has the following divine attributes: omnipotence, omniscience, and omnibenevolence (Everitt 2010). In other words, God is supposed to be omnipotent (all-powerful), omniscient (all-knowing), and omnibenevolent (all-good). (See, e.g., Plantinga 1974b, 1980; Adams 1983; Davis 1983; Morris 1987; Wierenga 1989; Gale 1991; MacDonald 1991; Rogers 2000; Mizrahi 2013). A well-known problem is that the reality of evil in the world flies in the face of this conception of God (see, e.g., Boyce 2011, pp. 371-384). The basic problem can be formulated as follows: 
(E1) God is all-powerful.

(E2) God is all-knowing.

(E3) God is all-good.

(E4) There is evil in the world.

(E5) The conjunction of (E1) \& (E2) \& (E3) \& (E4) is logically inconsistent because

1. If God were all-powerful, then God would be able to eliminate evil.

2. If God were all-knowing, then God would know how to eliminate evil.

3. If God were all-good, then God would want to eliminate evil.

Therefore:

(E6) Given (E4), God is either not all-powerful or not all-knowing or not all-good.

The problem is that (E6) is at odds with the aforementioned conception of God. This "logical problem of evil" seems to have few proponents these days (Dougherty 2011). Nowadays, a more modest claim is usually made, dubbed the "evidential problem of evil," according to which the reality of evil constitutes evidence against the existence of God and that evidence needs to be weighed against arguments for the existence of God (see, e.g., van Inwagen 2006; Bishop and Perszyk 2011). 
In response to the problem of evil, some distinguish between moral evil and natural evil (see, e.g., Swinburne 1996, pp. 95-113), ${ }^{1}$ and then offer the free will defense as a response to the problem of moral evil (see, e.g., Plantinga 1974b, pp. 41-42). The distinction between natural evil and moral evil is supposed to capture the difference between evil for which moral agents are responsible (e.g., rape, murder, war, genocide) and "naturally occurring" evil for which no moral agent is responsible (e.g., famine, disease, natural disasters). As Madden and Hare (1968, p. 6) write, natural evil includes

the terrible pain, suffering, and untimely death caused by events like fire, flood, landslide, hurricane, earthquake, tidal wave, and famine and by diseases like cancer, leprosy and tetanus - as well as crippling defects and deformities like blindness, deafness, dumbness, shriveled limbs, and insanity by which so many sentient beings are cheated of the full benefits of life.

Moral evil, on the other hand, includes "both moral wrong-doing such as lying, cheating, stealing, torturing, and murdering and character defects like greed, deceit, cruelty, wantonness, cowardice, and selfishness" (Madden and Hare 1968, p. 6). Likewise, according to Swinburne (2004, p. 236), natural evil includes "bad desires that we cannot help, disease, and accidents.",2 It is important to note that, if one thinks of God as a moral agent, as some do, then one could argue that natural evil is also evil that results from the actions of a moral agent, namely,

\footnotetext{
${ }^{1}$ According to Poston (2012, pp. 166-185), the natural/moral evil distinction goes back to Augustine.

${ }^{2}$ See also van Inwagen (2006, p. 9) on natural or physical evil.
} 
God (see, e.g., Flint 1998, pp. 84-90). So perhaps it would be better to say that moral evil is evil for which human moral agents are responsible. Indeed, in characterizing moral evil, Swinburne (2004, p. 236) says that moral evils are "those brought about by human intentional choice, or knowingly allowed to occur by humans, together with the evils of their intentional bad actions or negligence" (emphasis added). In that case, a theist could argue that human moral agents have free will, which is a gift from God, and that is why humans are responsible for moral evil, not God. This is known as the free will defense.

As far as natural evil is concerned, one influential response to the problem of natural evil is due to Swinburne. According to Swinburne (1996, p. 110):

God has the right to allow natural evils to occur (for the same reason as he has the right to allow moral evils to occur) - up to a limit. It would, of course, be crazy for God to multiply evils more and more in order to give endless opportunity for heroism, but to have some significant opportunity for real heroism and consequent character formation is a benefit for the person to whom it is given. Natural evils give to us the knowledge to make a range of choices between good and evil, and the opportunity to perform actions of especially valuable kinds (original emphasis).

In other words, even though natural evil seems to make it unlikely that an omnipotent, omniscient, and omnibenevolent God exists, God in fact has a good reason for allowing natural evil. The reason is that natural evil gives human persons opportunities to act in heroic and 
otherwise morally praiseworthy ways. Let us call this response to the problem of natural evil the “character-forming” or “soul-making” defense (cf. Hick 1966, pp. 255-256).

In what follows, I argue that there is a kind of evil- heretofore unmentioned in the literature, to the best of my knowledge ${ }^{3}$ - for which the free will defense and the soul-making defense are not adequate responses. In the next section, then, I explain what this kind of evil is and why it poses a new evidential (not logical or incompatibility) problem of evil. In Section 3 , I argue that the free will defense is not an adequate response to this new evidential problem of evil. In Section 4, I argue that the soul-making defense is not an adequate response to this new evidential problem of evil.

\section{Natural inequality}

The sort of evil I have in mind is natural inequality or bad luck that is the result of what John Rawls calls "the natural lottery." Consider what Rawls (1999, p. 63) says about the natural lottery:

the outcome of the natural lottery is arbitrary from a moral perspective.

By “outcomes of the natural lottery," Rawls means the family one is born into, whether one is born male or female, a member of this or that ethnic group, a member of this or that social class, and, most importantly, the natural talents one is born with, among other things. All these things are "arbitrary from a moral point of view" because they are undeserved. For example, one does

\footnotetext{
${ }^{3}$ Cf. two recent discussions of the problem of evil: Adams (2006) and Adams (2011).
} 
not "deserve" to be born male or female. Similarly, one does not "deserve" to be naturally gifted in abstract reasoning or in sports.

Furthermore, according to Rawls (1999, p. 63):

the most obvious injustice of the system of natural liberty is that it permits distributive shares to be improperly influenced by these factors [i.e., natural talents and abilities] so arbitrary from a moral point of view.

If Rawls is right, then natural endowments are arbitrary from a moral point of view. To say that natural endowments are arbitrary from a moral point of view is to say that natural endowments are undeserved. Now, if natural endowments are undeserved, then the fact that one person is more innately endowed than another is arbitrary from a moral point of view. In that case, if one person has more natural talents or is more talented than another person, then that is an unequal distribution of natural talents. From a moral point of view, it is not fair that one person is taller, healthier, faster, thinner, more intelligent, more beautiful, more agile, and otherwise more naturally endowed than another person. Both did not deserve their shares of natural talents (or lack of natural talents, for that matter). The talented do not deserve to be talented just as the untalented do not deserve to be untalented. More generally, the haves do not deserve to have just the have-nots do not deserve not to have.

Now, since moral arbitrariness in the distribution of natural endowments gives rise to unequal distributions, which are unfair because they are undeserved, as when some (e.g., Albert 
Einstein) get all the cognitive goods, whereas others (e.g., microcephalics) get nothing, the problem is to say how could God-who is supposed to be omnipotent, omniscient, and omnibenevolent—allow for this sort of natural inequality. In other words, if God is morally perfect, why is the distribution of natural endowments so unequal? How could an all-good God be so unfair in distributing natural endowments? This is the problem of natural inequality, which is a new evidential (not logical or incompatibility) problem of evil, or so I argue.

It is important to note that natural inequality is an evil, not because it leads to pain and suffering, although it might and often does, but because it is unfair. All things being equal, if there are four slices of pizza, and you get three and I get only one, then this unequal distribution is not fair, since you do not deserve to get more and I do not deserve to get less (and vice versa). Such an unequal and unfair distribution, I take it, is a bad thing from a moral point of view, even if it does not lead to pain and suffering directly (although it might). Similarly, if some people are born with superior athletic talents, say, whereas others are born handicapped, then that is an unequal distribution of athletic talents. This unequal distribution is also unfair because the athletically gifted did not deserve to be so gifted just as the handicapped did not deserve to be handicapped. Again, an unequal and unfair distribution of anything, whether it is pizza, goods, or talents, is a bad thing from a moral point of view, not because it leads to pain and suffering, although it might and often does, but because it is unfair. That is why natural inequality, i.e., the unequal distribution of natural endowments, is a bad thing from a moral point of view, not because it leads to pain and suffering, although it might and often does, but because it is unfair.

Natural inequality presents theists with a new evidential problem of evil for the following reasons. First, natural inequality is a new evidential problem of evil because it has to do, not with pain or suffering per se, but rather with an unequal distribution. Accordingly, although 
Swinburne mentions disease, specifically cancer, in his lists of natural evils (see, e.g., 2003, p. 166 and 2004, p. 242), this is not the same as the problem of natural inequality. The former, i.e., Swinburne's natural evil, has to do with pain and suffering, whereas the latter, i.e., natural inequality, has to do with an unequal distribution of natural endowments. That is, the problem is not why there is pain, suffering, and death that are caused by diseases such as cancer if there is an omnipotent, omniscient, and omnibenevolent God. Rather, the problem is why there is inequality if there is an omnipotent, omniscient, and omnibenevolent God. More specifically, if God is all-powerful, all-knowing, and all-good, then why some have so much more (in terms of natural endowments) than others? How could a morally perfect God allow for such inequality? How could God be so unfair in the distribution of natural endowments?

In that respect, natural inequality is also different from what Poston (2012) calls "social evil.” According to Poston (2012, p. 167):

Social evil is an instance of pain or suffering that results from the game-theoretic interactions of many individuals. When a social evil occurs, responsibility for the outcome lies with no particular person and no impersonal force of nature; rather it lies with a group of people, each of whom may be morally in the clear (emphasis added).

Social evil, then, is an instance of pain or suffering. Natural inequality, however, is not an instance of pain or suffering per se, although it might and often does lead to pain and suffering. Instead, natural inequality refers to the unequal and unfair distribution of natural endowments. Whether an unequal and unfair distribution of shares leads to pain and suffering or not, the mere 
fact that it is unfair is a bad thing from a moral point of view. The problem, then, is how a morally perfect and just God could be responsible for such an unfair distribution of natural endowments.

\section{Natural inequality and the free will defense}

Since the point of the free will defense is to shift the responsibility for moral evil from God to human persons, theists could try to use the free will defense in order to respond to this new evidential problem of evil, namely, the problem of natural inequality. More explicitly, theists could reason as follows:

(a) The fact that the unequal distribution of natural endowments is unfair is still our fault, not God's. It is our fault because what counts as "losing" or "winning" in the natural lottery is determined by social arrangements. Currently, human societies are arranged in such a way that those who are more innately endowed than others get most of the goods.

(b) The fact that the unequal distribution of natural endowments is unfair is still our fault, not God's. It is our fault because even the losers in the natural lottery still have free will, and they can choose how they respond to their bad luck.

I think that both (a) and (b) fail as "free will" responses to the problem of natural inequality. Here is why. Regarding (a), consider microcephalics. Clearly, the natural lottery has not been kind to them. Would we say that microcephalics are "losers" in the natural lottery simply because social arrangements are such that they cannot thrive or enact their conception of the 
good life for a human being? I doubt it. In fact, it is difficult to imagine any social arrangement at all in which microcephalics can flourish, since they lack the capacity to do so regardless of the society in which they happen to live. If this is correct, then some drawings of the natural lots are so unfair no matter what kind of social arrangements are in place. For this reason, the free will defense is an inadequate response to the problem of natural inequality.

Regarding (b), consider microcephalics again. Can microcephalics really choose how to respond to their bad luck? I doubt it. The same can be said of newborns with Tay-Sachs disease, Down syndrome, Patau syndrome, Edwards syndrome, and so on. ${ }^{4}$ So it seems that there are some drawings of the natural lots that limit one's choices in ways that interfere with one's ability to flourish or enact one's conception of the good life for a human being. Now, if God is a providential God, i.e., "all that occurs in the universe takes place under Divine Providence - that is, under God's sovereign guidance and control" (McCann 2012), then God also controls the natural lottery. In other words, natural endowments are gifts from God. But if natural endowments are gifts from God, then God is responsible for the unequal distribution of natural endowments, which makes some people unable to respond to God appropriately. Clearly, if one is a microcephalic, it is not one's fault that one cannot respond to God appropriately, since one did not receive from God the natural endowments that are needed in order to do so. In that case, one's free will is irrelevant. That is to say, one's inability to respond to God appropriately cannot be attributed to a misuse of one's free will, given that God did not give one the "tools," as it were, to get the job done.

\footnotetext{
${ }^{4}$ According to Lobo and Zhaurova (2008), "Every year, an estimated 7.9 million infants (6\% of worldwide births) are born with serious birth defects."
} 
If this is correct, then some drawings of the natural lots make one unable to respond to God appropriately. And the fact that one cannot do so is not one's fault, even if one has free will, since one never had the ability to do so in the first place (as a result of one's bad luck in the natural lottery). For this reason, too, the free will defense is not an adequate response to the problem of natural inequality.

At this point, some might want to incorporate Plantinga's (1974a, p. 58) suggestion that natural evil may be due to the immoral actions of supernatural beings other than God (cf. Lewis 1957, p. 122) and argue that natural inequality is also due to the immoral actions of supernatural beings other than God. However, there are two problems with this move. First, whether evil is caused by human beings or supernatural beings, it is still the case that God allows it to occur, given that "all that occurs in the universe takes place under Divine Providence - that is, under God's sovereign guidance and control" (McCann 2012). Similarly, even if natural inequality is due to the actions of supernatural beings other than God, it is still the case that God allows it. But how could he? After all, God is supposed to be all-good and just.

Second, recall that the problem of natural inequality is an evidential problem of evil, not a logical or incompatibility problem of evil. In that case, although it is logically possible (perhaps even metaphysically possible) that there are supernatural beings whose immoral actions account for natural evil and natural inequality, it is highly unlikely. At any rate, we have no evidence for the existence of such supernatural beings, let alone that they are responsible for natural evil and/or natural inequality.

\section{Natural inequality and the soul-making defense}


Since the point of the soul-making defense is to show how natural evil is necessary insofar as it gives human persons opportunities to act in morally praiseworthy ways, theists could try to use the soul-making defense in order to respond to the problem of natural inequality. More explicitly, theists could reason as follows:

(c) The unequal distribution of natural endowments, although unfair, is necessary insofar as it allows some to care for the "naturally unlucky" in character-forming or soul-making ways.

I think that (c) fails as a "soul-making" response to the problem of natural inequality. Here is why. Even if the fact that a human being is microcephalic allows others to care for him or her in morally praiseworthy ways, the fact that this particular human is microcephalic, whereas others are more cognitively endowed, remains unfair. Does this particular human "deserve" to be microcephalic? No; because the natural lottery is arbitrary from a moral point of view, i.e., natural endowments are undeserved. Do those who care for him or her "deserve" their superior cognitive endowments? No; because the natural lottery is arbitrary from a moral perspective. This state of affairs, then, is unfair. More generally, no one deserves to be a loser in the natural lottery just as no one deserves to be a winner in the natural lottery. For this reason, the soulmaking defense is not an adequate response to the problem of natural inequality.

To this some might object that the soul-making defense succeeds once it is granted that natural inequality allows for morally praiseworthy responses. That is, the fact that some are naturally unlucky gives those who are naturally lucky opportunities to act in morally 
praiseworthy ways. That is an adequate justification for natural inequality unless it can be shown that natural inequality is such a great evil that it is not worth the opportunities for soul-making, so to speak, or so the objection goes.

This objection, however, merely pushes the problem of natural inequality one step further. In other words, even if soul-making provides an adequate justification for the unequal distribution of natural endowments, it does not justify the unequal distribution of soul-making opportunities. After all, soul-making opportunities are also a good to be distributed. Why is it that some get more soul-making opportunities than others? And why should they? Since they do not deserve those soul-making opportunities, the fact that they got them, whereas others did not, and the fact that some get more soul-making opportunities that others are unfair, given that both natural endowments and soul-making opportunities are undeserved.

To put it another way, the unequal distribution of soul-making opportunities amounts to a violation of the first condition of Rawls' second principle of justice. According to Rawls (2001, p. 42), "Social and economic inequalities are [...] to be attached to offices and positions open to all under conditions of fair equality of opportunity." The natural lottery is such that losers do not have a fair shot at soul-making opportunities, given that soul-making opportunities can be taken advantaged of only if one has the requisite natural endowments, as the aforementioned case of microcephalics shows.

In fact, since there are winners and losers in the natural lottery, and since the winners win both natural endowments and soul-making opportunities, given that natural endowments enable the winners to take advantage of soul-making opportunities, whereas the losers lose both natural endowments and soul-making opportunities, since the losers' lack of the requisite natural 
endowments makes them unable to take advantage of soul-making opportunities, one could argue that natural inequality is a greater evil. In other words, the winners win twice over: they win natural endowments and, as a result, soul-making opportunities. On the other hand, the losers lose twice over: they lose natural endowments and, as a result, soul-making opportunities. This creates greater inequality in terms of natural endowments as well as soul-making opportunities.

To put it another way, the unequal distributions of natural endowments and of soulmaking opportunities amount to a violation of the second condition of Rawls' second principle of justice. According to Rawls (2001, pp. 42-43), "Social and economic inequalities [...] are to be to the greatest benefit of the least-advantaged members of society (the difference principle)." Since the winners in the natural lottery win not only natural endowments but also soul-making opportunities, and since the losers in the natural lottery are the least-advantaged members of society, it follows that the unequal distributions of natural endowments and soul-making opportunities do not benefit the least-advantaged members of society.

To this last point (i.e., that the winners of the natural lottery win twice over, whereas the losers of the natural lottery lose twice over, because being lucky in terms of natural endowments is linked with being lucky in terms of soul-making opportunities) it might be objected that the losers of the natural lottery still get some soul-making opportunities, just not of the kind that the winners of the natural lottery get. For example, the winners must battle their pride and remain humble while providing assistance to the worse-off, whereas the losers must have proper selfesteem and humility in accepting assistance from the well-off. 
This objection is problematic for the following reasons. I am not sure that, say, infants with Tay-Sachs disease, who usually die by the age of four, have any soul-making opportunities at all. But even if they do have some soul-making opportunities, I think that natural lottery winners have much more soul-making opportunities, in terms of both degree and kind, for the simple fact that being a natural lottery winner usually comes with additional benefits, such as better health, longer life expectancy, and so on. First, all things being equal, a person with a life expectancy at birth of approximately seventy years has more soul-making opportunities, on average, than a person with a life expectancy of approximately four years. ${ }^{5}$ Second, in virtue of living longer, winners get not only more but also different kinds of soul-making opportunities that losers never get. For instance, an infant that dies from Tay-Sachs disease at the age of four will never get the opportunity to feed the hungry, provide shelter for the homeless, care for the sick, defend the weak, and so on.

Along similar lines, some might also object that everyone, winners and losers alike, are equally placed with respect to the most valuable gift of all, namely, the beatific vision. However, there are two problems with this line. First, the beatific vision is supposed to be a gift that one receives in another world, not in this world. So the extreme inequality in terms of natural endowments and soul-making opportunities in this world remains a problem. Second, since the problem of natural inequality is an evidential, not a logical or incompatibility, problem of evil, we need evidence for the existence of an afterlife, heaven, and immortal souls, at the very least, for this objection to go through. Absent such evidence, the beatific vision remains a logical (perhaps even a metaphysical) possibility that is ineffective as an objection against the evidential problem of natural inequality.

\footnotetext{
${ }^{5}$ According to the World Health Organization, seventy years was the average life expectancy at birth of the global population in 2011 (http://www.who.int/gho/mortality burden disease/life tables/situation trends/en/).
} 
Finally, some might object that God owes us nothing. That is, God does not have to make sure that natural endowments are equally distributed or that they are distributed in such a way that benefits the least-advantaged members of society. Likewise, God does not have to make sure that soul-making opportunities are equally distributed or that they are open to all under conditions of fair equality of opportunity. God doesn't owe us anything, or so the objection goes.

The question of what a perfectly good God owes us humans deserves a paper of its own. In this paper, I am concerned simply with articulating a new problem of evil, namely, the problem of natural inequality. As an objection against the problem of natural inequality, however, this objection seems to come dangerously close to asserting that principles of justice are depended on God's will. The problems with this claim are well-known (see Plato's Euthyphro, 10a; 1997, p. 9). That is, to paraphrase Socrates, is the just (or fair) just (or fair) because it is loved by God or does God love it because it is just (or fair)?

More importantly, however, this objection seems to miss the point of the problem of natural inequality. Since the outcomes of the natural lottery are arbitrary from a moral point of view, winners do not deserve their good fortune and losers do not deserve their bad fortune. So the problem is not that some get more than they deserve, whereas some do not get what they are owed. Rather, the problem is that some get much more than others, which is not fair precisely because the winners in the natural lottery do not deserve to win and the losers do not deserve to lose. If God is morally perfect, all-good, and just, then this sort of unfairness is a problem, not because God owes us anything, but because it is just not fair that, in the words of Rod Stewart,

Some guys [and gals] have all the luck, whereas 
Some guys [and gals] have all the pain,

when they do not deserve it (the luck or the pain), given that the outcomes of the natural lottery are arbitrary from a moral perspective.

\section{Conclusion}

In this paper, I have argued that there is a kind of evil, namely, the unequal distribution of natural endowments, or natural inequality, which presents theists with a new evidential (not logical or incompatibility) problem of evil. The problem of natural inequality is a new evidential problem of evil for the following reasons. First, in discussing the problem of evil, contemporary authors usually focus on pain and suffering that are caused by natural disasters, disease, and the like, rather than the unequal distribution of innate talents and abilities. Second, two of the major available theodicies, namely, the free will defense and the soul-making defense, are not adequate responses to the problem of natural inequality.

Acknowledgments. I would like to thank Marcus Arvan, Elisa Freschi, Daniel Greco, David Morrow, and Walter Riker for helpful discussion. I am also grateful to an anonymous reviewer of Philosophia for helpful comments on earlier drafts.

\section{References}

Adams, M. M. (2011). Julian of Norwich: Problems of Evil and the Seriousness of Sin. Philosophia, 39, 433-447. 
Adams, R. (1983). Divine Necessity. Journal of Philosophy, 80, 741-746.

Adams, R. M. (2006). Love and the Problem of Evil. Philosophia, 34, 243-251.

Bishop, J. and Perszyk, K. (2011). The Normatively Relativized Logical Argument from Evil. International Journal for Philosophy of Religion, 70, 109-126.

Boyce, K. (2011). Non-Moral Evil and the Free Will Defense. Faith and Philosophy, 28, 371384.

Davis, S. (1983). Logic and the Nature of God. Grand Rapids, MI: Wm. B. Eerdmans.

Dougherty, T. (2011). Recent Work on the Problem of Evil. Analysis, 71, 560-573.

Everitt, N. (2010). The Divine Attributes. Philosophy Compass, 5, 78-90.

Flint, T. P. (1998). Divine Providence: The Molinist Account. Ithaca, NY: Cornell University Press.

Gale, R. (1991). On the Existence and Nature of God. New York: Cambridge University Press.

Hick, J. (1966). Evil and the God of Love. New York: Harper and Row.

Lewis, C. S. (1957). The Problem of Pain. London: Fontana Books.

Lobo, I. and Zhaurova, K. (2008) Birth defects: causes and statistics. Nature Education 1(1), http://www.nature.com/scitable/topicpage/birth-defects-causes-and-statistics-863.

MacDonald, S., Ed. (1991). Being and Goodness. Ithaca: Cornell University Press.

Madden, E. and Hare, P. (1968). Evil and the Concept of God. Springfield, IL: Charles C. Thomas. 
McCann, H. J. (2012). Divine Providence. In E. N. Zalta (Ed.), The Stanford Encyclopedia of Philosophy (Winter 2012 Edition),

http://plato.stanford.edu/archives/win2012/entries/providence-divine/.

Mizrahi, M. (2013). New Puzzles about Divine Attributes. European Journal for Philosophy of Religion, 5(2).

Morris, T. (1987). Perfect Being Theology. Noûs, 21, 19-30.

Plantinga, A. (1974a). God, Freedom, and Evil. New York: Harper and Row.

Plantinga, A. (1974b). The Nature of Necessity. Oxford: Clarendon Press.

Plantinga, A. (1980). Does God Have a Nature? Milwaukee: Marquette University Press.

Plato. (1997). Complete Works. J. M. Cooper and D. S. Hutchinson (Eds.). Indianapolis: Hackett Publishing Co.

Poston, T. (2012). Social Evil. In J. L. Kvanvig (ed.), Oxford Studies in Philosophy of Religion, vol. V (pp. 166-185). Oxford: Clarendon Press.

Rawls, J. (1999). A Theory of Justice. Revised Edition. Cambridge, MA: Harvard University Press.

Rawls, J. (2001). Justice as Fairness: A Restatement. E. Kelly (Ed.). Cambridge, MA: Harvard University Press.

Rogers, K. A. (2000). Perfect Being Theology. Edinburgh: Edinburgh University Press.

Swinburne, R. (1996). Is There a God? New York: Oxford University Press. 
Swinburne, R. (2003). Providence and the Problem of Evil. New York: Oxford University Press.

Swinburne, R. (2004). The Existence of God. $2^{\text {nd }}$ Ed. New York: Oxford University Press.

Van Inwagen, P. (2006). The Problem of Evil. New York: Oxford University Press.

Wierenga, E. (1989). The Nature of God. Ithaca: Cornell University Press. 